and after day 3 , it is likely that the eoncentration of the neurosecretory material in the in vitro experiments was great enough only on day 3 to give a marked result. It is clear that maximum synthesis and maximum release of leucine aminopeptidase occur at the same time.

We are thorofore persuaded that ecdysis in the Iarvaladult moult of Phocanema directly parallels exsheathmont in the infective larvae of trichostrongyles, and that the process in Phocanema is under neurosecretory control. Our standard culture medium, and presumably the intestine of seals, contain the necessary elements in tho stimulus leading to the release of neurosecretion, the consequent synthesis of leucine aminopeptidase, and the eventual cmergence of the adult worm from the fourth stage cuticle. Withholding this stimulus by culturing the worms in saline prevents the activity of the neurosecretory colls, the synthesis of leucine aminopeptidase by the excretory gland is abolished, and the worms fail to ecdyse.

This work was supported by a grant from the National Research Council of Canada.

K. G. Davey SAU PHeng Kan

Institute of Parasitology,

McGill University,

Macdonald Colloge P.O.,

P.Q., Canada.

' Rogers, W. P., The Nature of I'arasitism (Acadenie Press, London and New York, 1962).

${ }^{2}$ Rogers, W. P., and Sommerville, R. I., Parasitology, 50, 329 (1960).

${ }^{3}$ Rogers, W. P., and Sommerville, R. I., in Advances in Parasitology (edit. by Dawes, B.), 1, 109 (Academic Press, London and New York, 1963).

- Rogers, W. P., Comp. Biochem. Physiol., 14, 311 (1985).

'Lee, D. L., The Physiology of Nematodes (Oliver and Boyd, Fulinburgh,

${ }^{6}$ Meerovitch, F., Canad. J. Zool., 43, 81 (1965).

'Meerovitch, E., Proc. First Intern. Cong. Pnrasitology, 1, 081 (1966).

${ }^{8}$ Myers, B. J., Canad. J. Zool., 38, 331 (1980).

"Townsley, P. M., Wight, G. II., Scott, M. A., and Hughes, M. L., J. Fixh. Res. Board, Canada, $20,743(1963)$.

${ }^{10}$ Davey, K. G., Canad. J. Zool., 43, 997 (1965).

${ }^{11}$ Davey, K. G., Canad. J. Zool., 42, 731 (1964).

${ }^{12}$ Davey, K. G., Amer. Zoologist, 6, 243 (1966).

${ }^{13}$ Ishikawa, M., Kiseichugaku Zasshi, 10, 1 (1961) (in Japanese: English summary).

14 Cameron, M. I., and Stcele, J. E., Stain T'echnol., 34, 265 (1959).

${ }_{15}$ Pearse, A. E., Histochemistry, Theoretical and Applied, second ed. (J. and A. Churchiil, London, 1962).

\section{Heterotrophic Nitrogen Fixation by the Blue-Green Alga Anabaenopsis circularis}

I'T has been shown that the blue-grcen alga T'olypothrix tenuis can be grown heterotrophically in complete darkness if, as well as minoral nutrients, appropriate organic substances such as casamino-acid are supplied as sources of nitrogen and carbon'. The maximum values for the growth rate and final growth yield obtained in hetorotrophic conditions, however, were found to be far less than those attained in the usual autotrophic cultures.

Way $^{2}$ has found that a blue-grcen alga, Chlorogloea fritschii, can fix molecular nitrogen in the dark in a nitrogen-freo medium at the expense of organic nutrients. Best growth oecurred on suerose, and in the dark nitrogen fixation was greatest when this substrate was supplied. Some growth occurred on maltose, whoreas no growth took place with, for example, glucose, fructose, mannitol, acetate, pyruvate or $\alpha$-ketoglutarate.

We have found that another blue-greon alga, Anabaenopsis circularis ${ }^{3,4}$, has the same ability to grow in the dark. Greatest growth and greatest nitrogen fixation in the dark occurred on glucose in the absence of combined nitrogen. Next to glucoso, fructose, sucrose and maltose were most effectivo, whereas no growth or nitrogen fixation occurred on the following compounds: xylose, ribose, arabinose, rhamnose, mannose, galactose, sorbose, glucose-1-phosphate, trehalose, cellobioso, lactose, melibioso, raffinose, stachyose, inulin, dextrin, glycogen, othanol, glycerol, erythritol, munnitol, furmate, acotate, propionate, butyrate, lactate, pyruvate, caproate, laurate, myristate, oxalate, malonate, succinate, malate, tartarate, citrate, fumarate, gluconate, oxalacetate, acetoacetate, aconitate, or glutarate.

It is noteworthy that the two species of algae mentioned here can utilize, so far as is known, no organic substance other than sugar in nitrogen-free medium in the dark, and that they utilize different kinds of sugars. For the growth of Anabaenopsis in the dark, the optimum concentration was 0.5 per cent for glucose and 0.3 per cent for fructose and sucrose (Table 1).

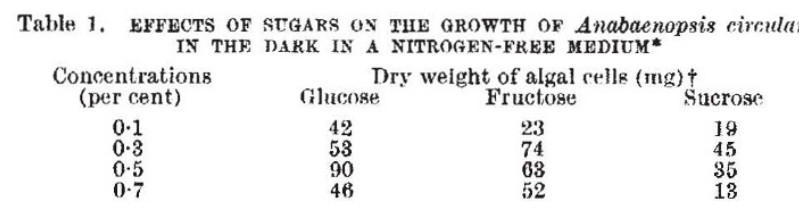

* Nitrogen-free media contained, in $1,000 \mathrm{ml}, 0 \cdot 25 \mathrm{~g}$ of $\mathrm{K}_{2} \mathrm{HPO}_{4}, 0 \cdot 25$ of $\mathrm{MgSO}_{4} .7 \mathrm{H}_{2} \mathrm{O}$, $0.05 \mathrm{~g}$ of calcium chloride, $0.05 \mathrm{~g}$ of sodium chloride, $2 \mathrm{~m}$ of ' $\mathrm{SSO}_{4}, 1 \mathrm{ml}$. of Arnon's $A_{5}$-solntion and the amounts indicated of sugars. + The weight of cells obtaincd from $100 \mathrm{ml}$. culture which were grow1 (without shaking) in the dark for 2 months at $32^{\circ} \mathrm{C}$.

Table 2. EFPECT OF LIGHT ON THE GROW'H OF Anabaenopsis circulteris

$$
\begin{array}{cccc}
\multicolumn{3}{c}{\text { Jight }} & \multicolumn{2}{c}{\text { I)ark }} \\
\text { No sugar } & \text { Fructose } & \text { No sugar } & \text { Fructose } \\
0.13 & 0.24 & 0 & 0.10
\end{array}
$$

* Figures refer to relative growth constant $(K g)$ estimated from the increase of packed cell volumes and expressed in $\log _{10}$ day $^{-1}$ units.

The effect of light on the growth of this alga was examined using 0.3 per cent fructose as the souree of carbon (Table 2). The heterotrophic growth of the alga is accelerated by light. Microscopic observations showed that a fairly large number of akinetes were formed in the hetero trophic culture in the dark.

The fact that these nitrogen-fixing algae can bo grown heterotrophically in the dark may be of practical interest. because it suggests the feasibility of growing them on a large scale in tanks to produce large quantities of algal materials to be used for agricultural purposes ${ }^{5}$.

Biological Laboratory,

Atsushi Watanabl:

Seijo University, Tokyo, Japan.

\section{YOKO УАMAMOTO}

Faculty of Agriculture, Meiji University, Tokyo, Japan.

Received January 31, 1967.

'Kiyohara, T., Fujita, Y., Hattori, A., and Watanałs, A.. J. Gen. App. Microbiol.' (Tokyo), B, 176 (1062).

${ }^{2}$ Fry, P., J. Gen. Microlriol., 39, 11 (1965).

${ }^{3}$ Watanabe, A., Nishigaki, S., and Konishi, C., Nature, 168, 748 (1951).

"Watanabe, A., J. Gen. App. Mierobiol., Tokyo, 5, 21 (1959).

"Watanabe, A., J. Gen. App. Mierobiol., Tokyo, 8, 85 (1962).

\section{Varietal Differences of Groundnut in the Production of Aflatoxin}

Toxic substances, known as aflatoxins, shown to cause acute liver damage in different species of animals, have beon domonstrated in mouldy groundnuts and groundnut meals ${ }^{1,2}$. These toxic metabolites are elaborated by certain strains of Aspergillus flavus which infest the groundnut crop in unfavourable conditions of collection, storage and transport. 'Thero havo been several roports ${ }^{3-5}$ of the conditions of growth of the fungus and production of aflatoxin in relation to agricultural practices involved in growing the groundnut crop. Surveys conducted in the coastal districts of Andhra Pradesh, India, and in the Riverain Provinces of Northern Nigeria ${ }^{4,5}$ have indicated that, with the agricultural practices prevalont in the 